$\begin{array}{cc}\text { ACADEMIA ROMÂNĂ } & \text { Rev. Roum. Chim., } \\ \text { 2019, 64(10), 841-847 }\end{array}$

\title{
FLUORIMETRIC DETERMINATION OF NITRATE IN WATER CATCHMENTS USING A FLUORESCENCE TRACER DYE
}

\author{
Catalina CIOATES NEGUT, Jacobus Frederick VAN STADEN* and Georgiana-Luiza ARNOLD TATU \\ Process Analytical Technology Laboratory (PATLAB) Bucharest, National Institute of Research and Development \\ for Electrochemistry and Condensed Matter (INCDEMC), 202 Splaiul Independenței Str., Bucharest 060021, Roumania
}

Received October 1, 2018

A simple, sensitive and selective fluorimetric method for the determination of trace amounts of nitrate in different water samples (e.g., geothermal waste water, drinking water from the spring, water surface, groundwater and waste water) was proposed. Some fluorescent dyes were investigated in a sequence of experiments to increase and optimize the response signal for reliable, suitable and sustainable determination of nitrate. [9-(2-carboxyphenyl)-6-diethylamino-3-xanthenylidene]diethylammonium chloride (Rhodamine B) was chosen for the direct fluorimetric determination of nitrate in an acetate buffer solution at a $\mathrm{pH}$ of 5.6. Under the optimum experimental conditions, nitrate can be determined in the range of $1.00 \times 10^{-4}-1.00 \times 10^{-3} \mathrm{~mol} \mathrm{~L}^{-1}\left(8.5-85 \mathrm{mg} \mathrm{L}^{-1}\right)$ with the detection limit $1.173 \times 10^{-6}$ $\mathrm{mol} \mathrm{L}^{-1}\left(0.1 \mathrm{mg} \mathrm{L}^{-1}\right)$. The results, obtained using the proposed method, were in agreement with those obtained by the standardized method SR ISO 7890-3:2000.

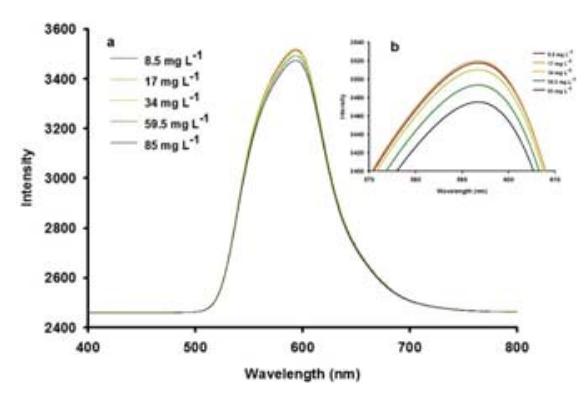

\section{INTRODUCTION}

Nitrite and nitrate are very much involved in the overall nitrogen cycle in soil and higher plants. ${ }^{1}$ Nitrates are found naturally in plants, is secreted in saliva and it has been used as additives in the food industry for a long time. ${ }^{2}$ Nitrate is a very important substance that is used widely in inorganic fertilizers in agricultural production. However with overloading and inefficient use of fertilizers in farming activities, agricultural run-off of nitrate becomes a major contributor to the eutrophication of fresh water rivers and lakes. Furthermore with the formation of fertilizing-by products from nitrate, these polluted substances become a hazard into different water areas and eventually with the intake from drinking water and food products hazardous to human health. ${ }^{3-9}$ A limit of $45 \mathrm{mg} \mathrm{L}^{-1}$ nitrate has been proposed for drinking water, since excessive concentrations lead to methaemoglobinaemia in infants. ${ }^{10}$ Excess concentration of nitrite and nitrate in drinking water is hazardous to health, especially for pregnant women. Main threats to health that arise from the ingestion of these ions are reported as "blue baby" syndrome and gastric cancer. ${ }^{11-18}$ These anions react with secondary amines in the acidic conditions of the stomach. The result is the production of carcinogenic nitrosamines which implicate in the pathology of gastric cancer. ${ }^{11,15}$ The determination of nitrate is therefore a very important factor in the analysis of soils, food and natural waters.

Several international organizations are involved with environmental issues or with human health, are in place to improve one or several aspects of drinking water nutrient efficiency and some have imposed strict limits regarding the maximum quantity of contaminants that can be found in drinking water. The current standards established

\footnotetext{
* Corresponding author: koosvanstaden2012@yahoo.com, koosvanstaden@patlab.ro,website: www.patlab.ro
} 
by the US Environmental Protection Agency (EPA) for drinking water are $1 \mathrm{mg} \mathrm{L}^{-1}$ for nitritenitrogen $\left(\mathrm{NO}_{2}^{-}-\mathrm{N}\right), 10 \mathrm{mg} \mathrm{L}^{-1}$ for nitrate-nitrogen $\left(\mathrm{NO}_{3}^{-}-\mathrm{N}\right)$ and $10 \mathrm{mg} \mathrm{L}^{-1}$ for the sum of $\mathrm{NO}_{2}^{-}-\mathrm{N}$ and $\mathrm{NO}_{3}^{-}-\mathrm{N}^{19}$ The National Research Council (NRC) subcommittee on nitrate and nitrite in drinking water agreed that current drinking water standards of EPA for these anions are adequate to protect human health. ${ }^{20}$

The presence and level of nitrate in water pollution is therefore of great concern and various techniques having been developed over the years to detect and reduce the content in different water areas. $^{2,21-34}$ Furthermore as the simultaneous determination of nitrite and nitrate is extremely important in environmental chemistry, numerous analytical methods have therefore been presented in this regard. Techniques, used for simultaneous determination of nitrite and nitrate, include chromatography: for example high performance liquid chromatography ${ }^{22,23}$ and ion chromatography, ${ }^{24}$ electrochemical detection, ${ }^{25}$ electrothermal molecular absorption spectrometry, ${ }^{26}$ flow-injection with chemiluminescence detection ${ }^{27}$ or FIA with spectrophotometric methods ${ }^{28-30}$ (e.g. the Griess reaction $^{31-33}$ ) and capillary electrophoresis. ${ }^{34}$

We developed a novel innovative, simple, sensitive and selective fluorimetric method for the determination of nitrate. The novelty in the fluorimetric determination is the fluorescent dye, [9(2-carboxyphenyl)-6-diethylamino-3-xanthenylidene]diethylammonium chloride (Rhodamine B) in an acetate buffer solution at a $\mathrm{pH}$ of 5.6. The proposed method has been successfully applied to the determination of nitrate in different water catchments and the results obtained compared favorably with the results from standard ISO certified methods.

\section{RESULTS AND DISCUSSION}

Preliminary tests were first done with some of fluorescent dyes such as Malachite Green and Rhodamine B. All the experiments were performed using solutions which contain the same concentrations of the individual dyes $(1.00 \mathrm{x}$ $\left.10^{-5} \mathrm{~mol} \mathrm{~L}^{-1}\right)$ with nitrate $\left(1.00 \times 10^{-4} \mathrm{~mol} \mathrm{~L}^{-1}\right)$ at different $\mathrm{pH}$ of acetate buffer solutions $(\mathrm{pH}=3-9)$, or nitrate alone at different acetate buffer solutions (Fig. 1).
As see in Fig. 1, nitrate without dyes and nitrate with Malachite Green at different $\mathrm{pH}$ of ABS have approximately the same intensity. An improvement in intensity was observed when Rhodamine B was used with nitrate and with a different $\mathrm{pH}$ of ABS. The results show that at $\mathrm{pH}=5.6$ in acetate buffer solutions with Rhodamine $B$ gave the best preliminary observations and were therefore selected for further experiments.

Figure 2 shows fluorescence spectra at different concentrations of Rhodamine B $1.00 \times 10^{-8} \mathrm{~mol} \mathrm{~L}^{-1}$ $\left(0.01 \mu \mathrm{mol} \mathrm{L}{ }^{-1}\right)-1.00 \times 10^{-4} \mathrm{~mol} \mathrm{~L}^{-1}\left(100.00 \mu \mathrm{mol} \mathrm{L}^{-1}\right)$ in $\mathrm{ABS}$ at $\mathrm{pH} 5.6$ and nitrate at $1.00 \times 10^{-4} \mathrm{~mol} \mathrm{~L}^{-1}$. It can be seen that the optimal concentration for Rhodamine B is $1.00 \times 10^{-5} \mathrm{~mol} \mathrm{~L}^{-1}\left(10 \mu \mathrm{mol} \mathrm{L}{ }^{-1}\right)$, with a maximum wavelength at $596 \mathrm{~nm}$.

\section{Response characteristic for the determination of nitrate}

The linear calibration curve of nitrate was obtained in the concentration range of $1.00 \times 10^{-4}$ $\mathrm{mol} \mathrm{L}^{-1}\left(8.5 \mathrm{mg} \mathrm{L}^{-1}\right)$ and $1.00 \times 10^{-3} \mathrm{~mol} \mathrm{~L}^{-1}(85.00$ $\mathrm{mg} \mathrm{L}^{-1}$ ) under the optimal conditions (Fig. 3). The linear regression equation was $\mathrm{I}=3529.1-$ $56511.31 \times \mathrm{C}$, where $\mathrm{I}$ is the fluorescence intensity and $\mathrm{C}$ is the nitrate concentration $\left(\mathrm{mol} \mathrm{L}^{-1}\right)$, respectively with correlation coefficient $\left(\mathrm{R}^{2}\right)$ 0.9976 (Fig. 4). The limit of quantification was found to be $1.00 \times 10^{-4} \mathrm{~mol} \mathrm{~L}^{-1}\left(8.5 \mathrm{mg} \mathrm{L}^{-1}\right)$ (was calculated as the lowest concentration from the linear range of concentration of calibration curve), the detection limit was $1.173 \times 10^{-6} \mathrm{~mol} \mathrm{~L}^{-1}$ $\left(0.1 \mathrm{mg} \mathrm{L} \mathrm{L}^{-1}\right.$ ) (was calculated with the excel function (forecast)) and the relative standard deviation $(\mathrm{N}=5)$ was $0.09 \%$ for $4.00 \times 10^{-4} \mathrm{~mol} \mathrm{~L}^{-1}$ $\left(34 \mathrm{mg} \mathrm{L}^{-1}\right)$ nitrate.

\section{Effects of foreign ions}

The effects of different foreign ions (cations and anions) on the determination of $4.00 \times 10^{-4} \mathrm{~mol} \mathrm{~L}^{-1}$ (34 $\mathrm{mg} \mathrm{L}^{-1}$ ) nitrate were also studied, and the results are summarized in Table 1 . The tolerance limit was defined as the concentration of foreign ion causing at least a $\pm 5 \%$ relative error in the fluorescence of the standard sample. As can be seen in the table, the proposed method give good selectivity, most of the ions examined have no influence on the determination of nitrate. 


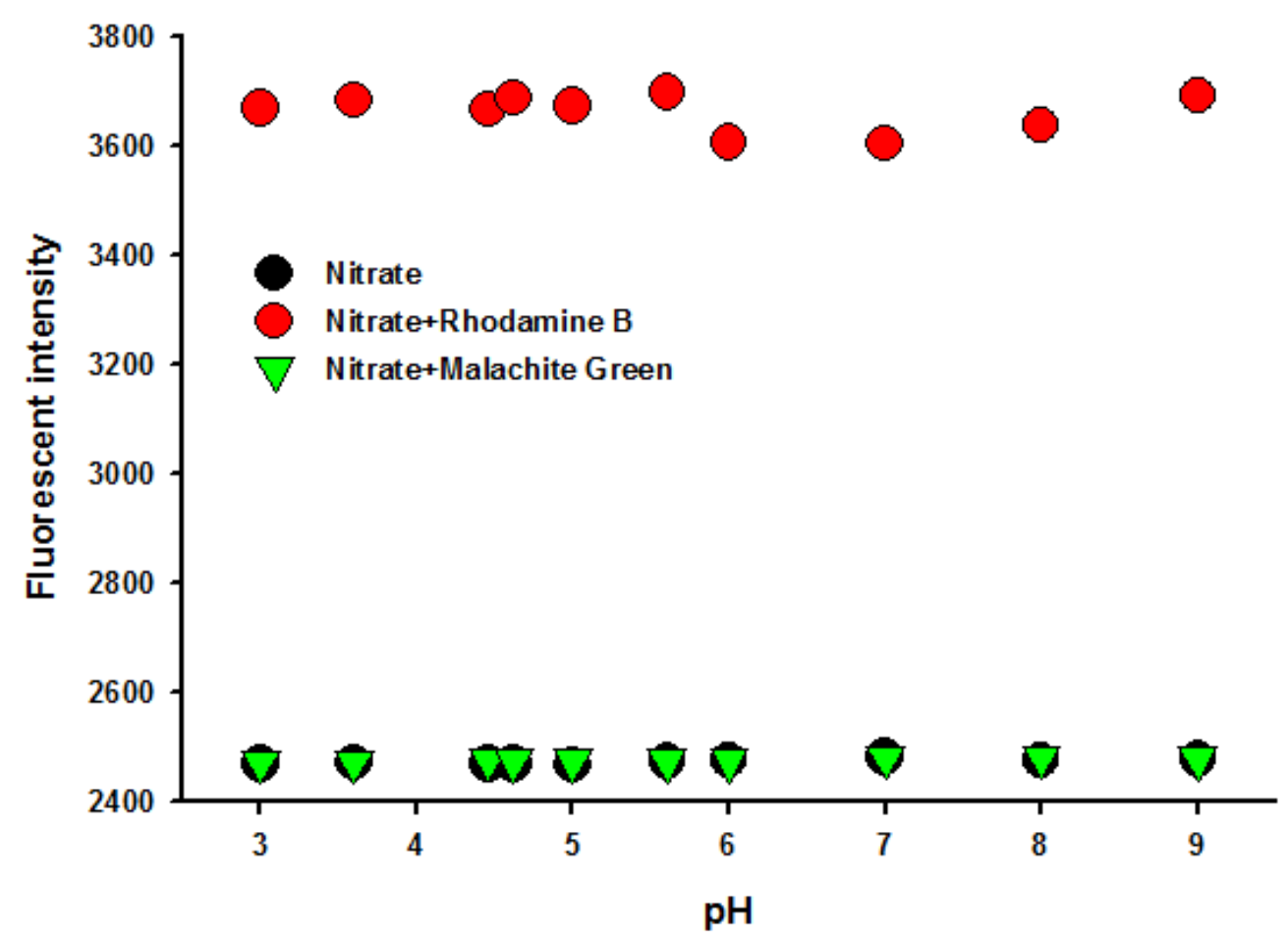

Fig. 1 - Effect of $\mathrm{pH}$ on the fluorescence intensity. The concentration of nitrate, Malachite Green, Rhodamine B were $1.00 \times 10^{-4} \mathrm{~mol} \mathrm{~L}^{-1}\left(8.5 \mathrm{mg} \mathrm{L}^{-1}\right), 1.00 \times 10^{-5} \mathrm{~mol} \mathrm{~L}^{-1}\left(100.00 \mu \mathrm{mol} \mathrm{L}^{-1}\right), 1.00 \times 10^{-5} \mathrm{~mol} \mathrm{~L}^{-1}\left(100.00 \mu \mathrm{mol} \mathrm{L}^{-1}\right)$ respectively.

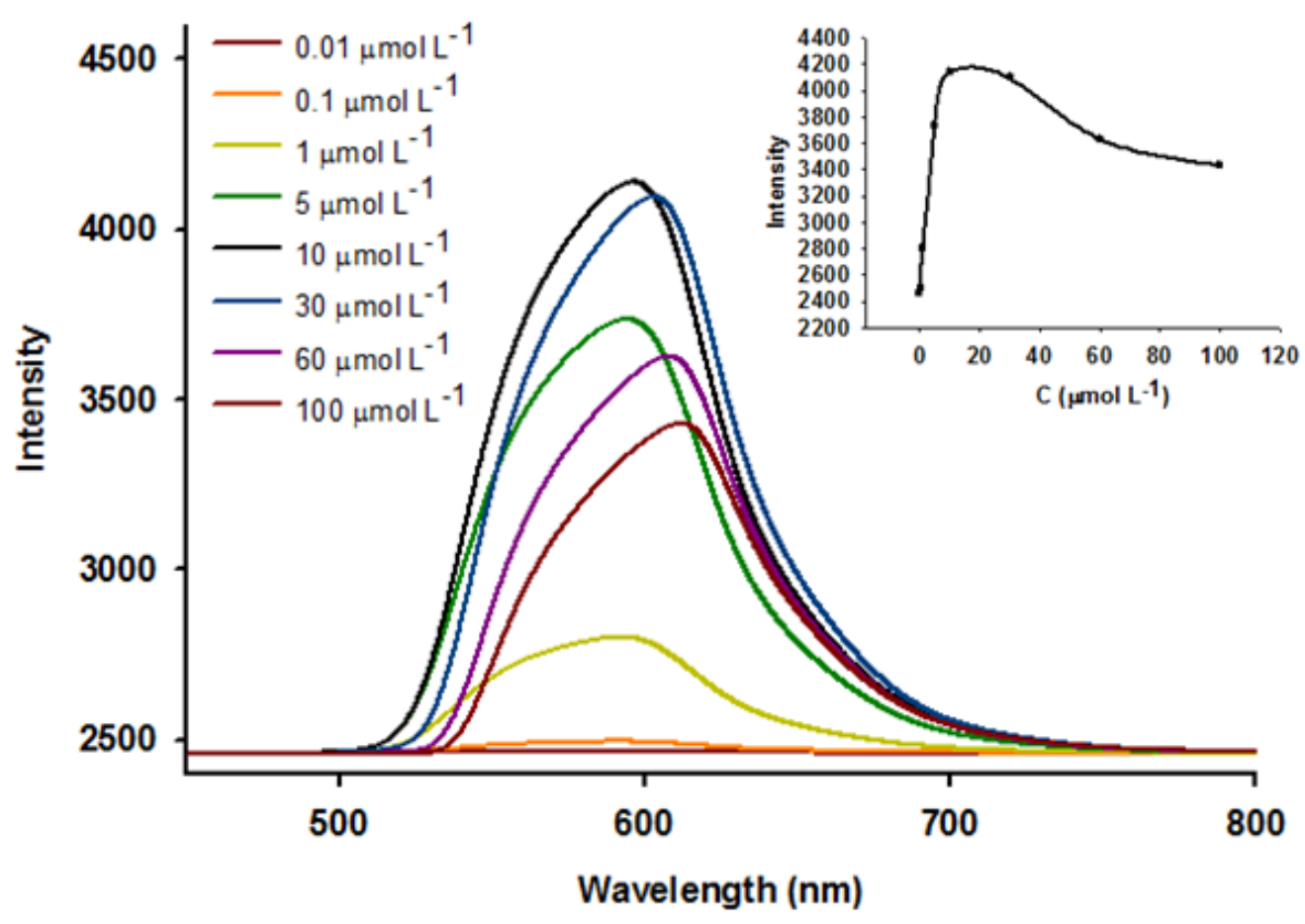

Fig. 2 - Fluorescence spectrum for the Rhodamine $\mathrm{B}$ at different concentration $1.00 \times 10^{-8} \mathrm{~mol} \mathrm{~L}^{-1}$ $(0.01 \mu \mathrm{mol} \mathrm{L}-1)-1.00 \times 10^{-4} \mathrm{~mol} \mathrm{~L}^{-1}\left(100.00 \mu \mathrm{mol} \mathrm{L}^{-1}\right)$ with $\mathrm{ABS} \mathrm{pH}=5.6$ and nitrate $1.00 \times 10^{-4} \mathrm{~mol} \mathrm{~L}^{-1}$ $\left(8.5 \mathrm{mg} \mathrm{L}^{-1}\right)$; inset: intensity $v$ s. concentration $\left(\mu \mathrm{mol} \mathrm{L} \mathrm{L}^{-1}\right)$ for the Rhodamine B. 


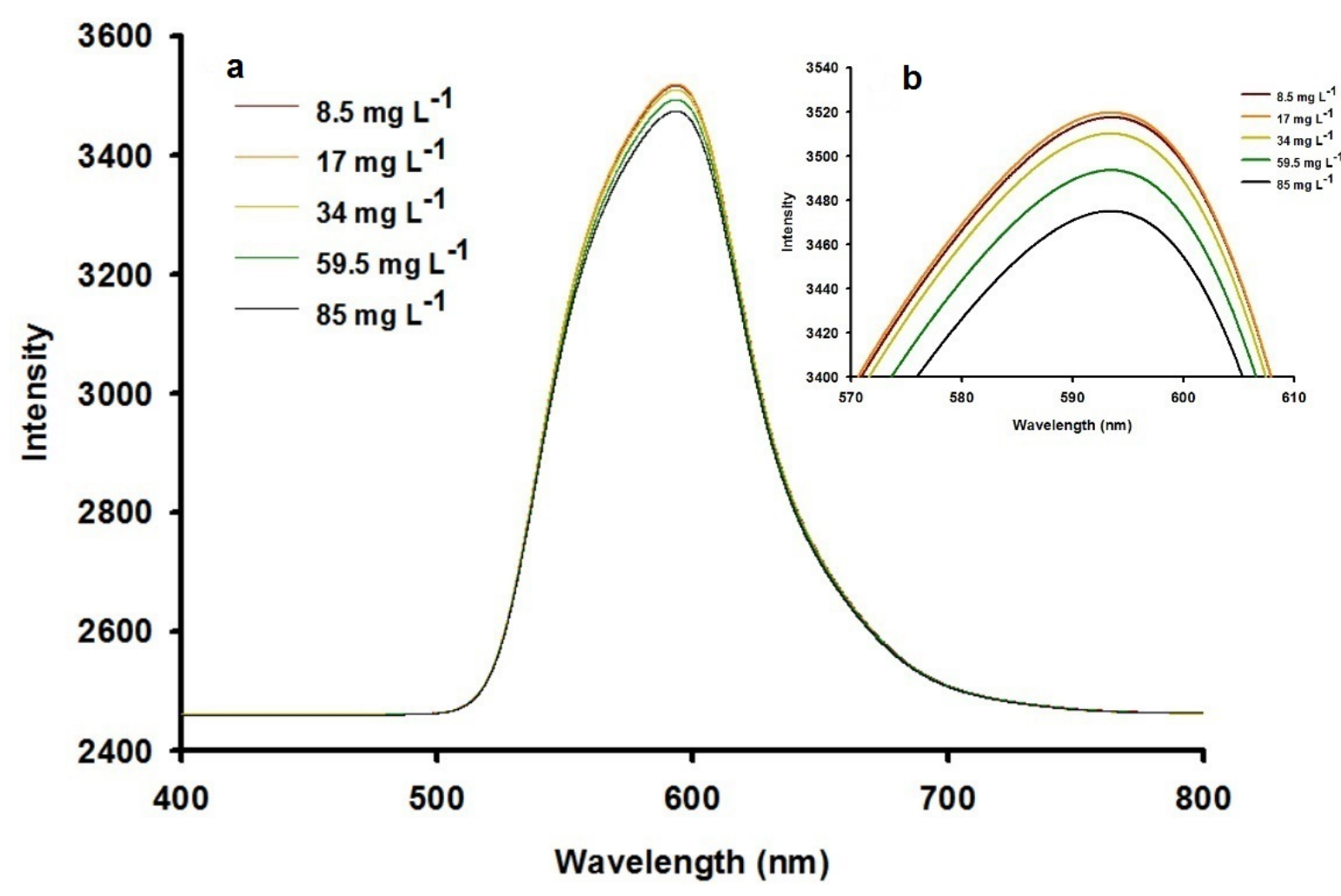

Fig. 3 - Fluorescence spectra of different concentration of nitrate. Conditions: $[\mathrm{RhB}]=1.00 \times 10^{-5} \mathrm{~mol} \mathrm{~L}^{-1}\left(10 \mu \mathrm{mol} \mathrm{L}{ }^{-1}\right)$, $\mathrm{pH}_{\mathrm{ABS}}=5.6$; inset: $\mathrm{a}$ - normal with baseline; $\mathrm{b}$ - enlargement.

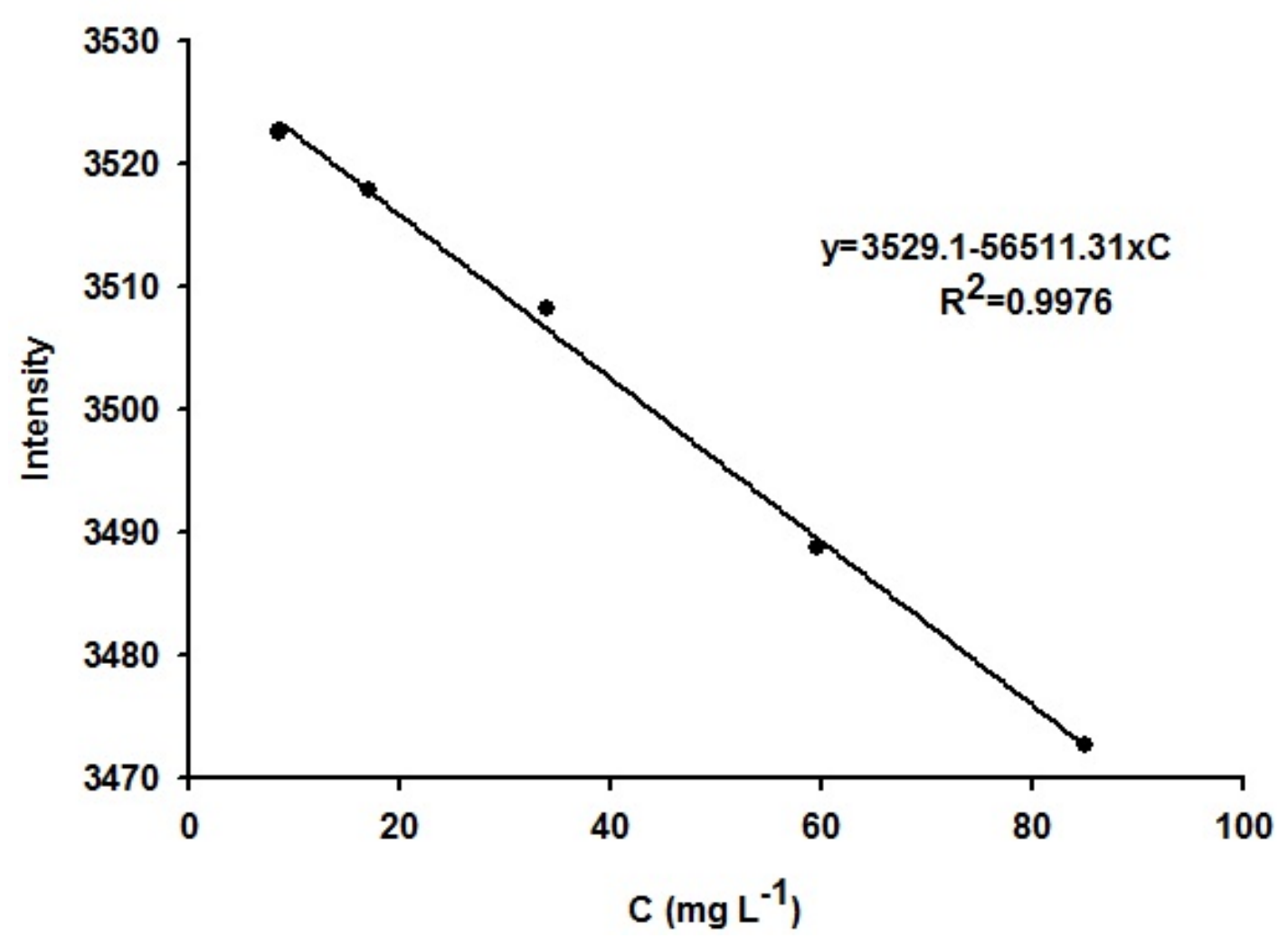

Fig. 4 - Calibration curve for the nitrate determination. 
Table 1

Tolerance limits of foreign ions in the determination of $4.00 \times 10^{-4} \mathrm{~mol} \mathrm{~L}^{-1}\left(34 \mathrm{mg} \mathrm{L}^{-1}\right)$ nitrate

\begin{tabular}{cc}
\hline Foreign Ions & Tolerance limit (molar ratio) \\
\hline $\mathrm{Br}^{-}$ & 1000 \\
$\mathrm{~K}^{+}$ & 500 \\
$\mathrm{SO}_{4}{ }^{2-}$ & 500 \\
$\mathrm{CO}_{3}{ }^{2-}$ & 500 \\
$\mathrm{HCO}_{3}{ }^{-}$ & 100 \\
$\mathrm{NO}_{2}^{-}$ & 50 \\
$\mathrm{Fe}^{2+}$ & 10 \\
$\mathrm{Co}^{2+}$ & 10 \\
$\mathrm{Zn}^{2+}$ & 10 \\
$\mathrm{Cu}^{2+}$ & 10 \\
$\mathrm{PO}_{4}{ }^{3-}$ & 10 \\
$\mathrm{Cl}^{-}$ & 10 \\
\hline
\end{tabular}

Table 2

Comparison between a standard method and the proposed method for nitrate determination in different water samples

\begin{tabular}{|c|c|c|c|c|}
\hline Sample & $\begin{array}{l}\text { Proposed method } \\
\qquad\left(\mathrm{mg} \mathrm{L}^{-1}\right)\end{array}$ & $\begin{array}{c}\text { Standard method } \\
\left(\mathrm{mg} \mathrm{L}^{-1}\right)\end{array}$ & $\%$, Recovery & $\%$, RSD $^{\mathbf{b}}$ \\
\hline Waste water (1) & 13.77 & 15.09 & 91.24 & 0.24 \\
\hline Network water (2) & 19.28 & 21.22 & 90.85 & 0.15 \\
\hline Groundwater (3) & 8.89 & 9.79 & 90.85 & 0.30 \\
\hline Sample 693 (4) & 27.34 & 30.13 & 90.74 & 0.02 \\
\hline $\begin{array}{c}\text { Drinking water from the } \\
\text { spring (5) }\end{array}$ & 10.98 & 12.11 & 90.64 & 0.01 \\
\hline $\begin{array}{c}\text { Drinking water from the } \\
\text { spring (6) }\end{array}$ & 36.70 & 40.48 & 90.67 & 0.09 \\
\hline Groundwater (7) & 1.20 & 1.32 & 90.77 & 0.13 \\
\hline Geothermal waste water (8) & 3.20 & 3.55 & 90.24 & 0.03 \\
\hline Water surface (9) & 5.57 & 6.16 & 90.37 & 0.13 \\
\hline $\begin{array}{l}\text { Drinking water from the } \\
\text { spring (10) }\end{array}$ & 18.28 & 20.23 & 90.38 & 0.11 \\
\hline
\end{tabular}

${ }^{\text {a }}$ Standard ISO certified methods (SR ISO 7890-3:2000).

${ }^{\mathrm{b}}$ Relative standard deviation for 5 measurements $(\mathrm{N}=5)$.

\section{Determination of nitrate in water samples}

The fluorimetric method was applied to the determination of nitrate in different water samples (e.g., geothermal waste water, drinking water from the spring, water surface, groundwater and waste water). The results presented in Table 2 show that the recoveries are between 90.24 and $91.24 \%$, and the relative standard deviation (RSD\%) was less than $0.4 \%(\mathrm{~N}=5)$. The results were compared with those obtained using the standard ISO certified method (spectrophotometric method using SR ISO 7890-3:2000 standard).
There is a good correlation between the results obtained using the proposed method and the standard ISO certified method for the assay of nitrate. A standard $t$-test was performed for two paired samples giving a good result for $t$ score. The value obtained (-4.0995) was comparate with the standard value for $t$ score (alpha level 0.05). The calculated $t$-value is greater than the table value at an alpha level of 0.05 . Standard $t$ score $=1.833$. Pvalue $=0.0027$, for $p<0.01$, statistical link is significant. The t-test results that the differences between the two paired samples are not significant. 


\section{EXPERIMENTAL PART}

\section{Reagents and materials}

Sodium nitrate, Malachite Green, Rhodamine B, acetic acid, sodium acetate, hydrochloric acid, sodium hydroxide were purchased from Sigma-Aldrich. All reagents were of analytical grade and solutions were prepared using deionized water obtained from a Direct-Q 3 Water Purification system (Millipore Corporation, France). All the working solutions were prepared daily by appropriate dilution of the stock solution with deionized water. All determinations were performed at room temperature $\left(25^{\circ} \mathrm{C}\right)$.

A standard stock solution of $1.00 \times 10^{-2} \mathrm{~mol} \mathrm{~L}^{-1}$ nitrate was prepared by dissolving $0.2125 \mathrm{~g}$ of sodium nitrate in $250 \mathrm{~mL}$ deionized water using the same precautions as previously described $^{28-30}$ and stored in a refrigerator.

Different acetate buffer solutions (ABS, $0.1 \mathrm{~mol} \mathrm{~L}^{-1}$ ) with pH 3-9 were prepared by mixing of appropriate volumes of $0.2 \mathrm{~mol} \mathrm{~L}^{-1}$ acetic acid and $0.2 \mathrm{~mol} \mathrm{~L}^{-1}$ sodium acetate solutions. The $\mathrm{pH}$ was adjusted with $0.1 \mathrm{~mol} \mathrm{~L}^{-1} \mathrm{HCl}$ or $\mathrm{NaOH}$ solutions to the required $\mathrm{pH}$ needed in the measurements.

Appropriate individual stock solutions for each of the following dyes, Malachite Green and Rhodamine B were prepared for preliminary testing. Stock solutions $1.00 \times 10^{-4} \mathrm{~mol}$ $\left.\mathrm{L}^{-1}(100.00 \mu \mathrm{mol} \mathrm{L})^{-1}\right)$ were prepared in deionized water for the following dyes: Malachite Green Rhodamine B. Working solutions of Rhodamine B were prepared by dilution of the stock solution with deionized water and kept in the dark.

\section{Apparatus}

A Mettler Toledo pH-meter (model Seven Compact) was used in order to adjust the $\mathrm{pH}$ at desirable values.

The fluorescence measurements were done with a spectrometer QE65000 from Ocean Optics (Dunedin, Florida) equipped with a xenon lamp (HPX 2000). The HPX-2000 Xenon Light Source is a high power, high-intensity source that is especially useful for fluorescence applications and for other applications where a high-intensity lamp is necessary. The QE65000 Scientific-grade Spectrometer is a very sensitive spectrometer. Results are acquired and processed using a Spectra Suite software program.

\section{Experimental procedure for nitrate calibration}

The solutions for the calibration curves were prepared in $10 \mathrm{~mL}$ volumetric flasks. The fluorescence intensity of each of the solutions was measured in a $1 \mathrm{~cm}$ quartz cell at a wavelength of $594 \mathrm{~nm}$ and room temperature $\left(25^{\circ} \mathrm{C}\right)$.

\section{Sample preparation}

Different water samples (e.g., underground water, geothermal waste water, domestic waste water and drinking water) from a variety of water catchments were provided by the National Institute of Research and Development for Industrial Ecology (INCD-ECOIND). These water samples were already pre-analyzed by standardized laboratory methods with standard ISO certified methods for nitrate.

\section{CONCLUSIONS}

The proposed fluorimetric method has the advantages of simplicity, high sensitivity and selectivity for the determination of nitrate in different water samples. The current method was compared with standard ISO certified method and was successfully applied to the determination of nitrate in water catchments with satisfactory results.

Acknowledgements. The authors gratefully acknowledge the National Research and Development Institute for Industrial Ecology - INCD-ECOIND Bucharest for standard ISO-certified samples and the Roumanian National Authority for Scientific Research, UEFISCDI for financial support, under grants PN-IIIP2-2.1-PED-2016-0181 and PN-III-P4-ID-PCE-2016-0050.

\section{REFERENCES}

1. H.O. Buckman and N.C. Brady, "The Nature and Properties of Soils", 7th Edition, Macmillan, New York, (Chapter 16), 1969.

2. Q.-H. Wang, L.-J. Yu, Y. Liu, L. Lin, R.-G. Lu, J.-P. Zhu, L. He and Z.-L. Lu, Talanta, 2017, 165, 709-720.

3. A. Menció, J. Mas-Pla, N. Otero, O. Regàs, M. BoyRoura, R. Puig, J. Bach, C. Domènech, M. Zamorano, D. Brusi and A. Folch, Sci. Total Environ., 2016, 539, 241-251.

4. F. T. Wakida and D. N. Lerner, Water Res., 2005, 39, 3-16.

5. M. L. Cortesi, L. Vollano, M. F. Peruzy, R. Marro and R. Mercogliano, CyTA J. Food, 2015, 13, 629-634.

6. W. Lijinsky, Mutat. Res. Genet. Toxicol. Environ. Mutagen., 1999, 443, 129-138.

7. A. S. Pannala, A. R. Mani, J. P. E. Spencer, V. Skinner, K. R. Bruckdorfer, K. P. Moorev and C. A. Rice-Evans, Free Radic. Biol. Med., 2003, 34, 576-584.

8. P. Santamaria, J. Sci. Food Agr., 2006, 86, 10-17.

9. WHO/SDE/WSH/07.01/16/Rev/1., 2016.

10. A. D. Eaton, L. S. Clescheri, A. E. Greenberg, "Standard Methods for the Examination of Water and Wastewater", $19^{\text {th }}$ Edition, American Public Health Association, Washington, 1995.

11. P. F. Swann, J. Sci. Food. Agr., 1975, 26, 1761-1770.

12. C. S. Bruning-Fann and J. B. Kaneene, Vet. Hum. Toxicol., 1993, 35, 521-538.

13. A. D. Eaton, L. S. Clescheri, A. E. Greenberg, "Standard methods for the examination of water and wastewater", $16^{\text {th }}$ Edition, American Public Health Association, New York, 1978.

14. R. D. Cox and C. W. Frank, J. Anal. Toxicol. 1982, 6, $148-152$.

15. M. A. Kuiper, J. J. Visser, P. L. Bergmans, P. Scheltens and E. C. Wolters, 1994, J. Neurol. Sci., 121, 46-49.

16. B. McNally, J. L. Griffin and L. D. Roberts, Mol. Nutr. Food Res., 2016, 60, 67-78.

17. P. Carter, L. J. Gray, J. Troughton, K. Khunti and M. J. Davies, Br. Med. J., 2010, 341, 1-8.

18. A. Ghasemi and S. Jeddi, Nitric Oxide, 2017, 70, 9-24.

19. EPA (Environmental Protection Agency), Fed. Reg., 1991, 56, 3526-3597.

20. NRC (National Research Council), "Nitrate and nitrite in drinking water", National Academy Press, Washington, DC, 1995.

21. M. J. Moorcroft, J. Davis and R. G. Compton, Talanta, 2001, 54, 785-803. 
22. Y. Zuo, C. Wang and T. Van, Talanta, 2006, 70, 281285.

23. S. H. Kok, K. A. Buckle and M. Wootton, J. Chromatogr. A, 1983, 260, 189-192.

24. K. Ito, Y. Takayama, N. Makabe, R. Mitsui and T. Hirokawa, J. Chromatogr. A., 2005, 1083, 63-67.

25. J. Davis, M. J. Moorcroft, S. J. Wilkins, R. G. Compton and M. F. Cardosi, Analyst 2000, 125, 737-742.

26. G. C. Brandao, G. D. Matos, R. N. Pereira, S. L. C. Ferreira, Anal. Chim. Acta, 2014, 806, 101-106.

27. M. Yaqoob, B. F. Biot, A. Nabi and P. J. Worsfold, Luminescence, 2012, 17, 419-425.
28. J. F. van Staden, Anal. Chim. Acta, 1982, 138, 403-408.

29. J. J. Pauer, H. R. van Vliet and J. F. van Staden, Water SA, 1990, 16, 105-108.

30. J. F. van Staden and M. A. Makhafola, S. Afr. J. Chem. 1999, 52, 49 - 54.

31. J. P. Griess, Proc. R. Soc. Lond., 1857, 9, 594-597.

32. J. P. Griess, Annalen der Chemie und Pharmacie, 1861, 17, 1-67.

33. J. P. Griess, Ueber einige Azoverbindungen Ber, 1879, $12,426-428$.

34. K. Fukushi, N. Ishio, M. Sumida, S. Takeda, S. Wakida and K. Hiiro, Electrophoresis, 2000, 21, 2866-2871. 
